REFERENSI : Jurnal Ilmu Manajemen dan Akuntansi Vol. 5 No. 1 Tahun 2017

THE INFLUENCE OF ETHICAL AWARENESS TOWARD THE COMMITMENT OF AUDITORS AT PUBLIC ACCOUNTANT FIRM IN MALANG

\author{
ECONOMICS COLLEGE OF GEMPOL \\ Email : hermi_sularsih@yahoo.co.id
}

\begin{abstract}
Due to the awareness of the profession possessed, auditors are supposed to carry out obligations indicating how auditors should act and behave according to ethic and rules in auditing. This research examines the influence of ethical awareness toward the commitment of auditors in public accountant office in Malang. Data analysis technique employed in this research is simple regression. The result of the research indicates that ethical awareness positively and significantly influences auditors' commitment. It means that if auditors have ethical awareness, they will have commitment to work according to the rules.
\end{abstract}

Keywords: Auditors, ethical awareness and professional commitment

\title{
PENGARUH KESADARAN ETIS TERHADAP KOMITMEN PROFESI AUDITOR PADA KANTOR AKUNTAN PUBLIK KOTA MALANG
}

\section{SEKOLAH TINGGI ILMU EKONOMI GEMPOL \\ Email : hermi_sularsih@yahoo.co.id}

\begin{abstract}
ABSTRAK
Kesadaran akan profesi yang diemban, seorang auditor melaksanakan kewajiban yang mengindikasikan bagaimana seorang auditor harus bertindak atau berperilaku sesuai kode etik dan aturan yang berlaku dalam mengaudit. Penelitian ini menguji pengaruh kesadaran etis terhadap komitmen profesi auditor pada kantor akuntan publik Kota Malang. Teknik analisis data yang digunakan dalam penelitian ini adalah regresi sederhana. Hasil penelitian adalah kesadaran etis berpengaruh positif secara signifikan terhadap komitmen profesi auditor artinya jika auditor memiliki kesadaran etis maka auditor memiliki komitmen dalam menjalankan profesi sesuai aturan.
\end{abstract}

Kata Kunci : Profesi Auditor, Kesadaran Etis dan Komitmen Profesi 


\section{REFERENSI : Jurnal Ilmu Manajemen dan Akuntansi Vol. 5 No. 1 Tahun 2017}

\section{PENDAHULUAN}

Profesi auditor diperlukan untuk dapat memberikan penilaian dan bertanggungjawab atas kewajaran laporan keuangan agar laporan keuangan tersebut tidak memberikan informasi yang menyesatkan kepada masyarakat dan pemakainya. Masyarakat sebagai pengguna laporan keuangan tentunya mengharapkan seorang auditor memberikan suatu jaminan mutlak yang berkaitan dengan hasil audit yaitu laporan auditor (Efendi dan Sujiono, 2004). Untuk mengetahui keberhasilan seorang auditor dan kinerja auditor dalam mengemban tugasnya, yaitu dengan menentukan berapa besar tingkat kompetensi yang dimiliki, profesionalisme seorang auditor, dan juga komitmen terhadap bidang yang ditekuninya.

Dalam mengemban tugasnya sebagai seorang auditor diatur oleh kode etik akuntan publik. Salah satu upaya profesi auditor mewujudkan perilaku yang profesional adalah kedisiplinan dalam pelaksanaan etika profesi yang telah ditetapkan oleh Ikatan Akuntan Indonesia mengenai Kode Etik Akuntan Indonesia. Kode etik akuntan publik bertujuan untuk menentukan standar perilaku bagi para akuntan, terutama auditor.

Rentannya profesi auditor pada kondisi dilemma disebabkan oleh suatu kondisi yang sulit dalam menentukan pilihan, hal ini merupakan tuntutan dari ikatan akuntan indonesia yang mengharuskan auditor untuk mematuhi kode etik yang berlaku dan kesadaran akan profesi yang dipertaruhkan apabila melanggar aturan, mulai dari standar pemeriksaan, etika profesi dan komitmen auditor, dalam kondisi ini diperlukan komitmen dan sikap yang profesional serta independensi yang kuat diperlukan (Mulyadi, 2007).

Kesadaran akan profesi yang diemban, seorang auditor melaksanakan kewajiban yang mengindikasikan bagaimana seorang auditor harus bertindak atau berperilaku sesuai kode etik dan aturan yang berlaku dalam mengaudit. Perilaku auditor yang diatur oleh kode etik ditetapkan dan dimonitor oleh organisasi profesi. Namun perilaku auditor juga dikendalikan oleh aturan-aturan yang ditetapkan oleh lembaga dimana seorang auditor bekerja. Kedua aturan tersebut tidak selalu sama dan auditor yang profesional akan terdorong mengutamakan salah satu sikap dibanding yang lainnya (Rahmawati dan Widagdo, 2001).

Muawanah dan Nur (2001) menyatakan bahwa kesadaran etik merupakan suatu tanggapan atau penerimaan seseorang terhadap suatu peristiwa berupa moral melalui suatu proses penentuan yang kompleks sehingga dia dapat memutuskan apa yang harus dia lakukan pada situasi tertentu. Keterbukaan terhadap moral yang berlaku sesuai kode etik dalam lingkungan auditor serta melaksanakan untuk kepentingan proses audit sangat diperlukan guna mencapai tingkat profesional dalam melaksanakan tugasnya.

Kesadaran etis auditor merupakan suatu tindakan sadar dari seorang auditor untuk melaksanakan tindakan yang professional apabila dihadapkan dengan keadaan dilema etis profesi (Sukrisno, 2009). Pentingnya kesadaran etis auditor sangat diperlukan untuk mewujudkan sikap profesional auditor. Dengan kesadaran etis yang dimiliki seorang auditor berarti sudah memahami standar profesi yang berlaku.

Banyak penelitian yang berkaitan dengan kesadaran etis auditor. Anisma dkk (2011) meneliti faktor yang mempengaruhi sikap skeptisme profesional seorang auditor menyatakan bahwa kesadaran etis seorang auditor dapat menentukan skeptisisme professional auditor. Amilin dan Desfiandi (2009) bahwa kesadaran etis berpengaruh signifikan terhadap perilaku auditor eksternal. Kesadaran etis dapat menentukan skeptisme professional auditor dan perilaku auditor 


\section{REFERENSI : Jurnal Ilmu Manajemen dan Akuntansi Vol. 5 No. 1 Tahun 2017}

eksternal secara signifikan. Namun, bagaimana pengaruh kesadaran etis terhadap komitmen profesi auditor pada kantor akuntan publik Kota Malang.

\section{TINJAUAN PUSTAKA DAN PENGEMBANGAN HIPOTESIS \\ Profesi Auditor}

Auditor dapat dikatakan suatu profesi karena auditor memiliki ciri-ciri yang dinyatakan oleh masyarakat profesi, sebagai suatu ciri-ciri suatu profesi (Basuki, 2001). Ciri-ciri yang dimaksud masyarakat adalah untuk menjadi seorang auditor harus mengikuti pelatihan yang ekstensif. Pelatihan untuk mencapai profesi auditor dilaksanakan setelah menempuh jenjang pendidikan sarjana akuntansi. Setelah sarjana akuntansi harus mengikuti pendidikan profesi akuntan dan lulus ujian sertifikasi yang diselenggarakan oleh lembaga profesi akuntan dan harus memiliki pengalaman sebagai seorang auditor. Ciri-ciri yang dimiliki auditor di atas dapat memberikan pengakuan masyarakat terhadap profesi seorang auditor.

Bertens (2007) menyatakan profesi auditor menjadi suatu kelompok yang memiliki kekuasaan sendiri dan karena itu mempunyai tanggung jawab khusus. Dengan kekuasaan yang dimiliki terhadap audit laporan keuangan auditor harus memperhatikan kode etik yang berlaku dalam melaksanakan proses audit laporan keuangan. Kode etik yang berlaku menyebabkan kepercayaan masyarakat atas profesi menjadi semakin kuat, karena bagi klien memerlukan kepastian bahwa kepentingannya akan terjamin.

\section{Kesadaran Etis}

Kesadaran etis adalah sebagai seperangkat prinsip moral atau nilai-nilai (Aren,2008). Kesadaran etis adalah situasi psikologis auditor yang harus dipertimbangkan dengan variabel personal lain yang lebih stabil sehingga dapat digunakan dalam memprediksi perilaku. Lawrence mengutarakan untuk pengembangan moral melalui enam tahapan yang dapat dimuat ke dalam tiga tingkatan alasan moral (Messsier et. al,2005), yaitu; 1) prekonvensional, individu yang dipautkan dengan dirinya sendiri. Aturan ditentukan secara eksternal pada individu. 2) konvensional, individu mampu mengamati situasi yang dilihat dari sudut pandang orang lain misalnya; keluarga, kelompok sejawat serta bangsa. 3) Pascakonvensional, hukum dan peraturan masyarakat dipertanyakan dan ditentukan kembali dalam hal prinsip moral universal.

\section{Komitmen Profesi}

Hall et al. (2005) menyatakan komitmen yang dimiliki auditor terhadap profesinya secara berkelanjutan dapat timbul karena auditor juga membutuhkan investasi untuk memperoleh atau mendapatkan profesinya sebagai seorang auditor, namun investasi sebagai auditor akan hilang jika auditor meninggalkan profesinya, yang meliputi keahlian dibidang auditing, status, atau penghargaan. Tidak hanya mempertahankan kualitas profesi yang sudah dimiliki, auditor untuk memperoleh kepercayaan yang berkelanjutan dari klien maupun masyarakat harus mengembangkan keilmuan sehingga dapat menyesuaikan kebutuhan kliennya. Salah satu komitmen auditor yang menunjukkan bahwa auditor berusaha untuk menjaga kualitas agar selalu profesional dalam menyelesaikan tanggung jawabnya adalah selalu mengikuti pelatihan yang berkaitan dengan aturan akuntan publik maupun kode etik akuntan publik.

\section{Gambar 1}

\section{Kerangka Pemikiran}

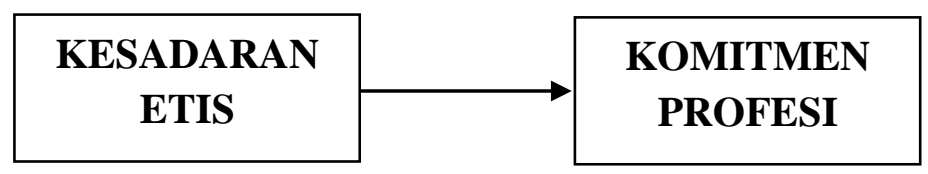


REFERENSI : Jurnal Ilmu Manajemen dan Akuntansi Vol. 5 No. 1 Tahun 2017

\section{Hipotesis Penelitian}

Telaah teoritis yang disampaikan di atas serta kerangka pemikiran dapat dirumuskan hipotesis yaitu; apabila Ho ditolak berarti kesadaran etis berpengaruh terhadap komitmen profesi auditor. Sedangkan Ho diterima berarti kesadaran etis tidak berpengaruh terhadap komitmen profesi auditor.

\section{METODE PENELITIAN}

\section{Lokasi Penelitian}

Obyek penelitian yang dilakukan pada auditor kantor akuntan publik kota Malang yang aktif memberikan jasa audit pada klien.

\section{Variabel Penelitian}

Variabel yang digunakan terdiri dari variabel bebas yaitu ; kesadaran etis (X) dan variabel terikat adalah komitmen profesi (Y).

\section{Teknik Pengumpulan Data}

Teknik pengumpulan data yang digunakan peneliti yaitu dengan menyediakan seperangkat pernyataan untuk dijawab secara langsung sesuai pendapat masing-masing auditor.

\section{Populasi dan Sampel Penelitian}

Seluruh auditor yang aktif bekerja pada kantor akuntan publik Kota Malang dan memiliki peluang yang sama untuk menjadi sampel penelitian ini dengan jumlah 30 Auditor.

\section{Teknik Analisis Data}

Teknik analisis data yang digunakan dalam penelitian ini adalah regresi sederhana. Sebelum melakukan uji hipotesis peneliti melakukan pengujian pada kualitas data.

\section{HASIL DAN PEMBAHASAN PENELITIAN Hasil Analisis Kualitas Data}

Analisis validitas digunakan untuk mengukur kemampuan item-item pernyataan kuesioner dalam pengumpulan data.
Tabel 1

Hasil Analisis Validitas

\begin{tabular}{|c|c|c|c|}
\hline $\begin{array}{c}\text { Item } \\
\text { Pernyataan }\end{array}$ & $\mathrm{X}$ & $\mathrm{Y}$ & Keterangan \\
\hline 1 & 0,628 & 0,391 & Valid \\
\hline 2 & 0,875 & 0,557 & Valid \\
\hline 3 & 0,585 & 0,377 & Volid \\
\hline 4 & 0,451 & 0,593 & ralla \\
\hline 5 & 0,631 & 0,413 & Valid \\
\hline 6 & 0,811 & 0,457 & Valid \\
\hline 7 & 0,684 & 0,615 & Valid \\
\hline 8 & 0,428 & 0,475 & Valid \\
\hline 9 & 0,875 & 0,557 & vala \\
\hline 10 & 0,744 & 0,603 & Valid \\
\hline 11 & 0,542 & 0,413 & Valid \\
\hline 12 & 0,730 & 0,446 & Valid \\
\hline 13 & 0,632 & 0,414 & Valid \\
\hline 14 & 0,441 & 0,542 & Valid \\
\hline 15 & 0,676 & 0,394 & \\
\hline 16 & 0,490 & 0,391 & Valid \\
\hline 17 & 0,461 & 0,402 & Valid \\
\hline 18 & 0,482 & 0,421 & Valid \\
\hline
\end{tabular}

Sumber : Data diolah, 2015

Tabel hasil analisis validitas diketahui nilai rhitung $>$ rtabel atau nilai rhitung $>0,361$ yang dinyatakan valid. Analisis reliabilitas terhadap item pernyataan variabel dengan Cronbach's Alpha menunjukkan nilai alpha semua variabel penelitian ini adalah lebih besar dari 0,6 dengan tingkat signifikan sebesar 0,05 artinya dapat dikatakan bahwa semua instrumen penelitian ini dinyatakan reliabel.

Tabel 2

Hasil Analisis Reliabelitas

\begin{tabular}{|l|c|c|}
\hline \multicolumn{1}{|c|}{$\begin{array}{c}\text { Variabel } \\
\text { Penelitian }\end{array}$} & $\begin{array}{c}\text { Cronbach's } \\
\text { Alpha }\end{array}$ & Keterangan \\
\hline $\begin{array}{l}\text { Kesadaran Etis } \\
(\mathrm{X})\end{array}$ & 0,852 & Reliabel \\
\hline $\begin{array}{l}\text { Komitmen } \\
\text { Profesi (Y) }\end{array}$ & 0,861 & Reliabel \\
\hline
\end{tabular}

Sumber : Data diolah, 2015 


\section{REFERENSI : Jurnal Ilmu Manajemen dan Akuntansi Vol. 5 No. 1 Tahun 2017}

\section{Hasil Analisis Asumsi Klasik \\ Hasil Analisis Normalitas}

Tabel 3

One-Sample Kolmogorov-Smirnov Test

\begin{tabular}{|l|ll|l|}
\hline & & & $\begin{array}{c}\text { Unstandardized } \\
\text { Residual }\end{array}$ \\
\hline $\mathrm{N}$ & a.b & Mean & 30 \\
Normal Parameters & & \\
& & Std. Deviation & 5,0223160000 \\
Most Extreme & & Absolute &, 113 \\
Differences & & Positive &, 113 \\
& & Negative &,- 078 \\
Kolmogorov- & &, 620 \\
$\begin{array}{l}\text { Smirnov Z } \\
\text { Asymp. Sig. (2- } \\
\text { tailed) }\end{array}$ & &, 836 \\
\hline
\end{tabular}

a. Test distribution is Normal.

b. Calculated from data.

Sumber : Data diolah, 2015

Analisis normalitas menggunakan tabel One-Sample Kolmogorov-Smirnov Test dengan nilai Asymp. Sig. (2-tailed) sebesar ,836 >0,05 yang menunjukkan data tersebar normal.

\section{Hasil Analisis Multikolinearitas}

Analisis menggunakan metode multikolinieritas dilakukan dengan metode enter berdasarkan pada tolerance value atau Variance Inflation Factor (VIF). Model regresi dapat di katakan bebas multikolinieritas adalah mempunyai besarnya nilai Variance Inflation Factor (VIF) 1 sampai 10 dengan nilai tolerance value mendekati 1 atau di atas 0,1 .

\section{Tabel 4}

Hasil Analisis Multikolinearitas

\begin{tabular}{|c|c|c|}
\hline \multirow{2}{*}{ Variabel } & \multicolumn{2}{|c|}{ Collinearity Statistic } \\
\cline { 2 - 3 } & Tolerance & VIF \\
\hline Kesadaran Etis & 0,861 & 1,162 \\
\hline
\end{tabular}

Sumber : Data diolah, 2015

Nilai Variance Inflation Factor variabel kesadaran etis sekitar 1 sampai 10 dengan nilai tolerance mendekati 1 atau diatas 0,1 yang artinya model regresi tidak terdapat masalah multikolinieritas.

\section{Hasil Analisis Heteroskedastisitas}

Dasar pengambilan keputusan apabila kesadaran etis secara statistik signifikan mempengaruhi komitmen profesi maka ada indikasi terjadi heterokedastisitas. Berdasarkan tabel hasil analisis heteroskedastisitas maka tidak terjadi unsur heteroskedastisitas.

Tabel 5

Hasil Analisis Heteroskedastisitas

\begin{tabular}{|c|c|c|}
\hline Variabel & $P$ Value & Keterangan \\
\hline Kesadaran Etis & 0,542 & Ho diterima \\
\hline
\end{tabular}

Sumber : Data diolah, 2015

\section{Hasil Analisis Regresi Sederhana}

Tabel 5

Hasil Analisis Regresi Sederhana

\begin{tabular}{|l|c|c|c|}
\hline \multicolumn{1}{|c|}{ Variabel } & $\begin{array}{c}\text { Koefisien } \\
\text { Regresi }\end{array}$ & $\begin{array}{c}\mathrm{t} \\
\text { hitung }\end{array}$ & Probabilitas \\
\hline Konstanta & 11,351 & - & - \\
\hline $\begin{array}{l}\text { Kesadaran } \\
\text { Etis }\end{array}$ & 0,907 & 5,768 & 0,000 \\
\hline $\begin{array}{l}\mathrm{N}=30 \\
\text { Sig. 0,05 }\end{array}$ & $\begin{array}{l}\mathrm{R}^{2} \text { Adjusted }= \\
0,639\end{array}$ \\
\hline
\end{tabular}

Sumber : Data diolah, 2015

Persamaan regresi sederhana dalam penelitian ini dirumuskan sebagai berikut :

$$
\mathrm{Y}=11,351+0,907 \mathrm{X}
$$

Konstanta sebesar 11,351 apabila variabel independen diasumsikan $=0$, maka nilai komitmen profesi secara konstan sebesar 11,351. Koefisien regresi X sebesar 0,907 memberikan arti bahwa kesadaran etis berpengaruh positif terhadap komitmen profesi. Hal ini menunjukkan bahwa dengan penambahan satu satuan kesadaran etis maka akan terjadi kenaikan komitmen profesi sebesar 0,907.

Dilihat dari nilai R2 Adjusted sebesar 0,639 menunjukkan bahwa besarnya pengaruh variabel kesadaran etis terhadap variabel komitmen profesi auditor adalah 63,9 \% sedangkan sisanya sebesar $36,1 \%$ dipengaruhi variabel lainnya. Untuk persamaan regresi sederhana di atas menunjukkan t hitung sebesar 


\section{REFERENSI : Jurnal Ilmu Manajemen dan Akuntansi Vol. 5 No. 1 Tahun 2017}

5,768 lebih besar dari t tabel 1,670 dengan signifikansi 0,000 lebih kecil dari 0,05 dengan demikian Ho ditolak berarti kesadaran etis berpengaruh secara signifikan terhadap komitmen profesi auditor.

Variabel kesadaran etis berdasarkan nilai t hitung lebih besar dari t tabel $(5,768>1,670)$ dengan signifikasi $0,000>0,05$ yang menunjukkan bahwa kesadaran etis mempunyai pengaruh positif secara signifikan terhadap komitmen profesi auditor di Kota Malang. Maka hipotesis peneliti lainnya yang menyatakan bahwa terdapat hubungan positif antara kesadaran etis terhadap komitmen profesi auditor dapat diterima. Kesadaran etis yang dimiliki auditor di Kota Malang merupakan suatu tanggapan atau sikap menerima seorang auditor terhadap suatu kejadian berupa moral tertentu melalui suatu proses yang ditentukan secara kompleks oleh auditor sehingga dapat mengambil keputusan apa yang harus yang akan dilakukan pada situasi tertentu. Hasil penelitian ini senada dengan penelitian Hasmanidar dan Wahyuningsih (2014) bahwa kesadaran etis memiliki pengaruh yang signifikan terhadap komitmen profesi yang dimiliki oleh akuntan publik yang ada.

\section{KESIMPULAN}

Kesadaran etis merupakan suatu sikap moral dimiliki auditor yang sadar terhadap etika profesi dan aturan lainnya yang berkaitan dengan profesi auditor dalam melaksanakan tugasnya, hal ini dapat dibuktikan pada penelitian saat ini yang menunjukkan bahwa kesadaran etis berpengaruh positif secara signifikan terhadap komitmen profesi auditor artinya jika auditor memiliki kesadaran etis maka auditor memiliki komitmen dalam menjalankan profesi sesuai aturan.

\section{Daftar Pustaka}

Agus, Sukrisno, 2009 , Etika Bisnis dan Profesi ,Salemba empat Jakarta.

Amilin dan Desfiandi, Andi. 2009. Pengaruh Audit Fee, Kesadaran Etis dan Locus Of Control terhadap Perilaku Auditor Eksternal. JMK vol. 7 No. 4, September 2009.

Anisma, Yuneita. Abidin, Zainal dan Cristina. 2011. Faktor yang Mempengaruhi Sikap Skeptisme Profesional Seorang Auditor pada Kantor Akuntan Publik di Sumatera.Pekbis Jurnal, Vol.3, No.2, Juli 2011: 490-497.

Arens, Alvin A., Randal J. Elder, and Mark S. Beasley. 2008. Auditing: An Integrated Approach. 12th ed. Upper Saddle River, NJ: Prentice Hall.

Bartens, K. 2007. Etika. PT. Gramedia Pustaka Utama. Jakarta.

Basuki, Sulistyo. 2001. Makalah Untuk Rapat Kerja PB IPI. Jurusan Ilmu Perpustakaan Fakultas Sastra Universitas Indonesia. Jakarta.

Efendi, David dan Sujiono. 2004. Pengaruh Kepuasan Kerja dan Motivasi Kerja terhadap Kinerja Individual. Jurnal Beta. Vol. 2, no. 2. 69-78.

Hall M., Smith D., and Langfiled-Smith K. 2005. “Accountant's Commitment to Their Profession: Multiple Dimensions of Professional Commitment and Opportunities for Future

Hasmanidar dan Eny, Wahyuningsih. 2014. Pengaruh Persepsi Profesi dan Kesadaran Etis terhadap Komitmen Profesi Akuntan Publik pada Kap di Pekanbaru. Jurnal Ekonomi, Manajemen dan Akutansi I Vol. 23 No. 2. Riau.

Messsier, Williams et. all, "Auditing \& Assurance Services a Systematic Approach (Jasa Audit \& Assurance 
REFERENSI : Jurnal Ilmu Manajemen dan Akuntansi Vol. 5 No. 1 Tahun 2017

Pendekatan Sistematis)", Buku 2 Edisi 4,

Salemba Empat, Jakarta, 2005.

Muawanah, Umi dan Nur Indriantoro. 2001.

"Perilaku Auditor Dalam Situasi Konflik

Audit: Peran Locus of Control,

Komitmen Profesi dan Kesadaran Etis".

Jurnal Riset Indonesia. Vol. 4.No. 2.

(Mey): $133-1$

Mulyadi, 2007, Pemeriksaan Akuntan (Auditing)

BPFE, Yogyakarta.

Rahmawati dan A. Widagdo. 2001. "Hubungan antara Komitmen Organisasi, Komitmen Profesi dengan Keinginan untuk Pindah dan Kepuasan Kerja melalui Konflik Peran pada Para Akuntan Indonesia”. Jurnal Akuntansi dan Bisnis, Vol. 1, No. $1: 1-12$

Research”. Behavioral Research in Accounting,

Vol. 17. pp. 89-109. 